\title{
Plaque removal by manual and electric toothbrushing among children
}

\section{Remoção de placa bacteriana pela escovação elétrica $e$ manual em crianças}

\author{
Carolina Covolo da COSTA* \\ Luiz Cesar da COSTA FILHO** \\ Marina Lara SÓRIA*** \\ Ana Paula Rorato MAINARDI****
}

\begin{abstract}
COSTA, C. C. da; COSTA FILHO, L. C. da; SÓRIA, M. L.; MAINARDI, A. P. R. Plaque removal by manual and electric toothbrushing among children. Pesqui Odontol Bras, v. 15, n. 4, p. 296-301, out./dez. 2001.

The purpose of this study was to compare the effectiveness of plaque control performed with electric and manual toothbrushes. Fifteen children with primary dentition and 14 children with mixed dentition were divided in two groups and randomly assigned to utilize a manual or an electric toothbrush. In the first session, professional plaque removal was performed, and the children spent 24 hours without brushing their teeth. In the second session, plaque was disclosed and assessed on all facial and lingual surfaces. After that, all children brushed their teeth with the predetermined toothbrush. The next procedure was the disclosure and measurement of residual plaque. After a period of 7 days, the children switched the kind of toothbrush, and the same procedures were repeated. According to the statistical analysis of the results, there were no significant differences concerning plaque removal when the toothbrushes were utilized by children with mixed dentition. On the other hand, the electric toothbrush promoted significantly greater plaque removal on the lingual surfaces of teeth from children with primary dentition.
\end{abstract}

UNITERMS: Oral hygiene; Toothbrushing; Dental devices, home care.

\section{INTRODUCTION}

The role of the accumulation of dental plaque in the development of dental caries and periodontal diseases is well established.

Although there is a great variety of methods available, mechanical plaque removal performed with a manual toothbrush remains the primary method to achieve good oral hygiene. Manual toothbrushing is highly effective if performed in a correct manner and during the correct amount of time. However, neither of these two criteria is usually fulfilled. A way to improve motivation during oral hygiene is to use an electric toothbrush, which, for some individuals, may enhance interest in oral hygiene and improve plaque removal ${ }^{11}$.

Some authors have shown that the electric toothbrush enhances tooth cleaning, elevating the levels of oral hygiene in areas where mechanical access is difficult (interproximal and lingual surfaces) and motivating patients toward daily oral hygiene. Regarding patients with poor oral hygiene, the electric toothbrushes can improve daily tooth cleaning, especially because plaque removal can be fast and easily carried out $t^{4,6,13}$. Furthermore, concerning a pediatric population aged between 8 and 12 years, the electric toothbrush can promote a significantly greater plaque removal from both primary and permanent teeth ${ }^{5}$.

On the other hand, some researchers such as AASS; GJERMO ${ }^{2}$ (2000) have shown that the electric toothbrush could hinder plaque removal by older patients (aged 18 to 60 years old). The authors suggest that the reason for that is the fact that those patients have practiced manual toothbrushing during years.

Considering the great importance of plaque removal in improving oral health, the objective of

\footnotetext{
${ }^{*}$ Private Practitioner; ${ }^{* * *}$ M.Sc., Professor of Pedodontics, Department of Stomatology, School of Dentistry - Federal University of Santa Maria (UFSM).

** M.Sc., Professor of Periodontics, Clinical Department; ***Graduate Student, Department of Preventive Dentistry - School of Dentistry, Pontifical Catholic University (PUC).
} 
COSTA, C. C. da; COSTA FILHO, L. C. da; SÓRIA, M. L.; MAINARDI, A. P. R. Plaque removal by manual and electric toothbrushing among children. Pesqui Odontol Bras, v. 15, n. 4, p. 296-301, out./dez. 2001.

this study was to compare the effectiveness of an electric toothbrush with that of a manual toothbrush, when utilized by children with primary and mixed dentitions.

\section{MATERIALS AND METHOD Subjects}

Fifteen children ( 7 girls and 8 boys) aged between 4 and 5 years old, with primary dentition, and 14 children ( 6 boys and 8 girls) aged between 10 and 12 years old, with mixed dentition, participated in the study. In the group of children with primary dentition, the sample consisted of 298 teeth, from which 596 surfaces were analyzed. Since each surface was assessed four times (before manual brushing, after manual brushing, before electric brushing and after electric brushing), a total of 2,384 measures was obtained. In the group with mixed dentition, the sample comprised 347 teeth, from which 694 surfaces were assessed. As well as in the group of children with primary dentition, each surface was assessed four times, providing a total of 2,776 measures.

A questionnaire about systemic health was applied, and the children's parents subscribed the informed consent.

Volunteers were not accepted if they had any physical condition that could limit manual dexterity. They were also not accepted if they had any oral disease or lesions, orthodontic bands or prosthetic appliances, accumulations of supragingival calculus or any other condition that could have any effect on the accumulation of plaque.

\section{Study design}

The study had a crossover single-blind design, which means that all children used electric and manual toothbrushes, and the examiner did not know what toothbrushing method each child was using.

Volunteers were then divided into two groups and were randomly assigned to use either the electric toothbrush (Braun Oral-B Ultra Plaque Remover) or the manual toothbrush (Squish Grip, Oral-B). In the same session, plaque was disclosed and removed by means of professional prophylaxis. Therefore, all participants initiated the experiment with the same condition (plaque index equal to zero).

Parents or guardians received written instructions explaining that their children should refrain from oral hygiene procedures and from the utilization of oral antiseptics for 24 hours. The volun- teers were classified according to the Silness \& Löe plaque index scores: 0 = lack of plaque; $1=$ plaque in the gingival third of the analyzed surface; $2=$ plaque in the gingival and medium thirds of the analyzed surface; and $3=$ plaque in the whole analyzed surface ${ }^{1}$. A calibrated examiner, who did not know which group the volunteers belonged to, performed all clinical examinations.

Children brushed their teeth for 2 minutes with their respective toothbrushes and performed two mouthwashes, with $10 \mathrm{ml}$ of water each, for 10 seconds, under supervision, but apart from the examiner. Immediately after the volunteers had brushed their teeth, whole-mouth plaque was assessed again.

For the next seven days, volunteers returned to their usual method of oral hygiene. After this period, they switched the kind of toothbrush, and all the children that had used the manual toothbrush restarted the whole process using the electric toothbrush and vice versa. From this moment on, all the procedures of the study were repeated.

\section{Statistical analysis}

The software Sigma Stat for Windows, version 1.0 (Jandel Corporation) was used. The statistical tests chosen were non-parametric because plaque measures were obtained as scores $(0,1,2$ and 3). The paired Wilcoxon Signed Rank test was used to compare plaque indices before and after toothbrushing. Values of $\mathrm{p} \leq 0.01$ were accepted as statistically significant.

\section{RESULTS \\ Children with primary dentition}

There were no significant differences between the groups, concerning the plaque indices before toothbrushing, on both analyzed surfaces (facial and lingual) ( $\mathrm{p}=0.04)$ (Table 1). This analysis showed the similarity of the groups (manual and electric toothbrushing) at the baseline.

No significant differences between the groups were seen, concerning the plaque indices of facial surfaces after toothbrushing $(\mathrm{p}=0.0187)$ (Table 1$)$.

There was a significant difference between the groups, regarding the plaque indices of lingual surfaces after toothbrushing. The group that utilized the electric toothbrush showed significant lower plaque scores on lingual surfaces $(\mathrm{p}=$ 0.0012) (Table 1). The lingual surfaces were then divided in anterior and posterior sections for a deeper analysis of the results. The group that uti- 
COSTA, C. C. da; COSTA FILHO, L. C. da; SÓRIA, M. L.; MAINARDI, A. P. R. Plaque removal by manual and electric toothbrushing among children. Pesqui Odontol Bras, v. 15, n. 4, p. 296-301, out./dez. 2001.

lized the electric toothbrush showed significant lower plaque indices on the lingual surfaces of anterior teeth $(\mathrm{p}<0.0001)$ (Graphs 1 and 2). When the plaque indices of the lingual surfaces of posterior teeth were assessed, no significant differences were found ( $\mathrm{p}=0.3783)$ (Graphs 3 and 4).

TABLE 1 - Plaque indices of facial and lingual surfaces before and after manual and electric toothbrushing in children with primary dentition.

\begin{tabular}{|c|c|c|c|c|c|}
\hline \multirow[b]{2}{*}{ Surface } & \multirow{2}{*}{$\begin{array}{l}\text { Plaque } \\
\text { indices }\end{array}$} & \multicolumn{2}{|c|}{ Before toothbrushing } & \multicolumn{2}{|c|}{ After toothbrushing } \\
\hline & & $\begin{array}{c}\text { Manual } \\
\text { toothbrush }\end{array}$ & $\begin{array}{c}\text { Electric } \\
\text { toothbrush }\end{array}$ & $\begin{array}{c}\text { Manual } \\
\text { toothbrush }\end{array}$ & $\begin{array}{l}\text { Electric } \\
\text { toothbrush }\end{array}$ \\
\hline \multirow{5}{*}{ Facial } & 0 & $0 \%$ & $0 \%$ & $51.34 \%$ & $63.09 \%$ \\
\hline & 1 & $43.28 \%$ & $51.68 \%$ & $41.61 \%$ & $30.20 \%$ \\
\hline & 2 & $41.28 \%$ & $37.58 \%$ & $6.38 \%$ & $6.71 \%$ \\
\hline & 3 & $15.44 \%$ & $10.74 \%$ & $0.67 \%$ & $0 \%$ \\
\hline & Total & $100 \%$ & $100 \%$ & $100 \%$ & $100 \%$ \\
\hline \multirow{5}{*}{$\begin{array}{l}\text { Lin- } \\
\text { gual* }\end{array}$} & 0 & $0 \%$ & $3.36 \%$ & $17.45 \%$ & $31.54 \%$ \\
\hline & 1 & $32.55 \%$ & $36.91 \%$ & $58.72 \%$ & $50.00 \%$ \\
\hline & 2 & $46.31 \%$ & $40.94 \%$ & $18.80 \%$ & $15.10 \%$ \\
\hline & 3 & $21.14 \%$ & $18.79 \%$ & $5.03 \%$ & $3.36 \%$ \\
\hline & Total & $100 \%$ & $100 \%$ & $100 \%$ & $100 \%$ \\
\hline
\end{tabular}

${ }^{*} \mathrm{p}=0.0012$.

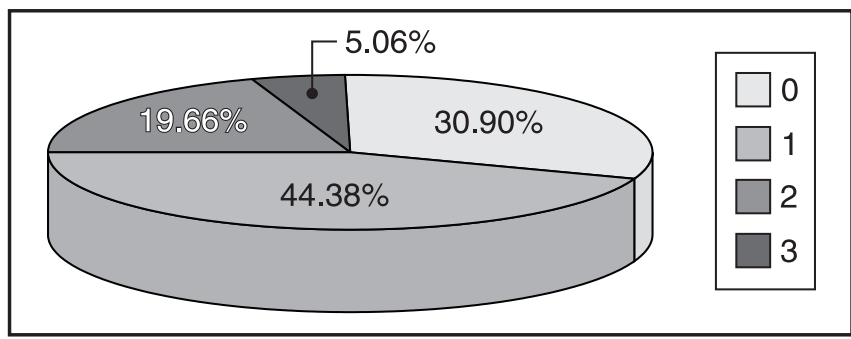

GRAPH 1 - Plaque indices of the lingual surfaces of anterior teeth after electric toothbrushing in children with primary dentition.

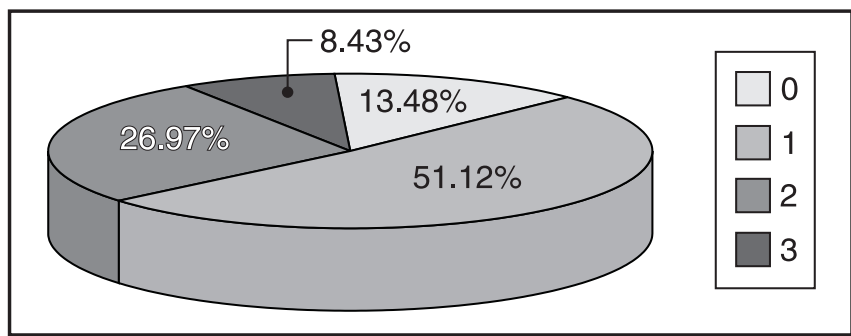

GRAPH 2 - Plaque indices of the lingual surfaces of anterior teeth after manual toothbrushing in children with primary dentition.

\section{Children with mixed dentition}

There were no significant differences between the groups, concerning the plaque indices obtained before toothbrushing on both analyzed surfaces (facial and lingual). This analysis showed the similarity of the groups (manual and electric toothbrushing) at the baseline.

The results regarding the plaque indices before and after toothbrushing showed that both types of toothbrushing could significantly reduce the plaque indices on all assessed surfaces $(p<0.01)$.

The results concerning the plaque indices of the facial surfaces of anterior teeth showed no significant differences between the groups $(p=0.9901)$ (Table 2). Similarly, no significant differences were seen between the groups, regarding the plaque indices of the facial surfaces of posterior teeth $(\mathrm{p}=0.5124)($ Table 3$)$.

There were no significant differences concerning the plaque removal from the lingual surfaces of anterior teeth, when manual and electric toothbrushes were compared $(p=0.4689)$ (Table 2). Similarly, no significant differences were seen between the groups, regarding the plaque indices of the lingual surfaces of posterior teeth $(p=0.0528)$ (Table 3).

\section{DISCUSSION}

Most studies that compare the effectiveness of

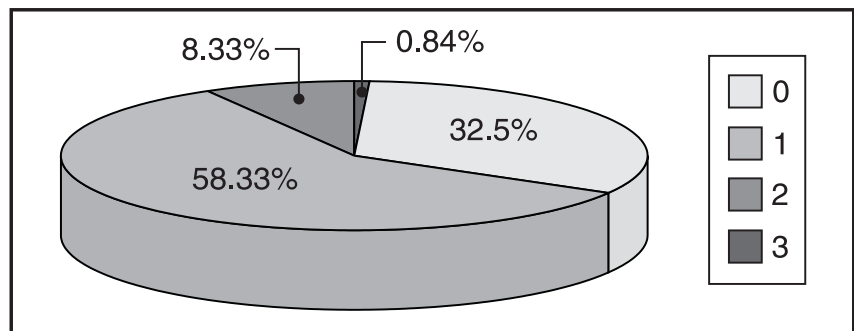

GRAPH 3 - Plaque indices of the lingual surfaces of posterior teeth after electric toothbrushing in children with primary dentition.

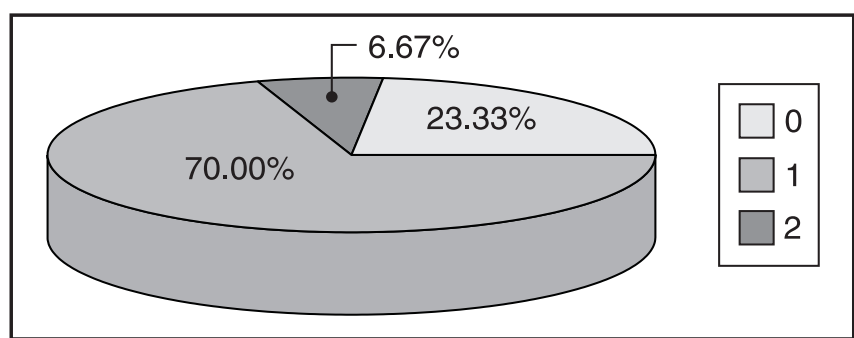

GRAPH 4 - Plaque indices of the lingual surfaces of posterior teeth after manual toothbrushing in children with primary dentition. 
COSTA, C. C. da; COSTA FILHO, L. C. da; SÓRIA, M. L.; MAINARDI, A. P. R. Plaque removal by manual and electric toothbrushing among children. Pesqui Odontol Bras, v. 15, n. 4, p. 296-301, out./dez. 2001.

TABLE 2 - Plaque indices of facial and lingual surfaces of anterior teeth after manual and electric toothbrushing in children with mixed dentition.

\begin{tabular}{c|c|c|c}
\hline \hline \multirow{4}{*}{ Surface } & Plaque indices & $\begin{array}{c}\text { Manual } \\
\text { toothbrush }\end{array}$ & $\begin{array}{c}\text { Electric } \\
\text { toothbrush }\end{array}$ \\
\hline \multirow{4}{*}{ Facial } & 0 & $73.46 \%$ & $74.07 \%$ \\
\cline { 2 - 4 } & 1 & $22.22 \%$ & $19.75 \%$ \\
\cline { 2 - 4 } & 2 & $3.70 \%$ & $4.94 \%$ \\
\cline { 2 - 4 } & 3 & $0.62 \%$ & $1.23 \%$ \\
\hline \multirow{4}{*}{ Lingual } & Total & $100 \%$ & $100 \%$ \\
\cline { 2 - 4 } & 2 & $36.42 \%$ & $30.86 \%$ \\
\cline { 2 - 4 } & 3 & $49.38 \%$ & $55.56 \%$ \\
\cline { 2 - 4 } & 1 & $11.11 \%$ & $8.64 \%$ \\
\cline { 2 - 4 } & Total & $100 \%$ & $4.94 \%$ \\
\hline \hline
\end{tabular}

electric toothbrushes with that of manual toothbrushes have been carried out with adult subjects ${ }^{5,9,12}$. However, the utilization of electric toothbrushes can improve ability in brushing techniques as well as manual dexterity. Theoretically, this kind of toothbrush has a particular value for children, for whom manual dexterity is considered a problem.

The groups (manual and electric toothbrushing) initiated the experiment with plaque indices statistically equivalent, since there were no significant differences between them, regarding baseline clinical indices. The papers of TRITTEN; ARMITAGE ${ }^{9}$ (1996) and WHITE ${ }^{15}$ (1996) endorse the present study.

The results showed that the manual toothbrush (Squish Grip - Oral-B) and the electric toothbrush (Braun Oral-B Ultra Plaque Remover) are capable of removing supragingival plaque in children aged from 4 to 5 years and from 10 to 12 years. These findings are in agreement with those of the studies carried out by ENGEL et al. ${ }^{3}$ (1993), TRITTEN; ARMITAGE $^{9}$ (1996) and AINAMO et al. ${ }^{1}$ (1997).

Children with primary dentition showed a better performance, concerning plaque removal, when they utilized the electric toothbrush. These findings are in agreement with those of the studies carried out by HEINTZE et al. ${ }^{6}$ (1996), in which the electric toothbrushes Rota-dent and Braun Oral-B Plaque Remover were compared with a manual toothbrush. This finding is also in agreement with the result of an 8-month study of VAN DER
TABLE 3 - Plaque indices of facial and lingual surfaces of posterior teeth after manual and electric toothbrushing in children with mixed dentition.

\begin{tabular}{c|c|c|c}
\hline \hline Surface & Plaque indices & $\begin{array}{c}\text { Manual } \\
\text { toothbrush }\end{array}$ & $\begin{array}{c}\text { Electric } \\
\text { toothbrush }\end{array}$ \\
\hline \multirow{4}{*}{ Facial } & 0 & $73.51 \%$ & $70.27 \%$ \\
\cline { 2 - 4 } & 1 & $17.84 \%$ & $17.84 \%$ \\
\cline { 2 - 4 } & 2 & $6.49 \%$ & $7.57 \%$ \\
\cline { 2 - 4 } & 3 & $2.16 \%$ & $4.32 \%$ \\
\hline \multirow{5}{*}{ Lingual } & Total & $100 \%$ & $100 \%$ \\
\cline { 2 - 4 } & 0 & $49.19 \%$ & $37.84 \%$ \\
\cline { 2 - 4 } & 1 & $48.65 \%$ & $58.92 \%$ \\
\cline { 2 - 4 } & 2 & $1.62 \%$ & $3.24 \%$ \\
\cline { 2 - 4 } & 3 & $0.54 \%$ & $0 \%$ \\
\hline \hline
\end{tabular}

WEIJDEN ${ }^{11}$ (1998), who found a statistically significant improvement in the modified gingival index and in bleeding on probing in subjects who were utilizing the Braun Oral-B Plak Control, when they were compared with subjects who were utilizing a manual toothbrush. Likewise, for WALMSLEY ${ }^{12}$ (1997), electric toothbrushes are superior, regarding plaque removal, to manual toothbrushes, and there are clinical evidences that a small rotating brush is better than a brush that performs a side to side motion. On the other hand, the same data contradicted the results of the study carried out by TRITTEN; ARMITAGE ${ }^{9}$ (1996), in which the electric toothbrush was not superior to the manual toothbrush, concerning plaque removal and the reduction of gingivitis.

There were no statistical differences regarding plaque removal from facial surfaces, when the toothbrushes were compared in children with primary dentition. On the other hand, it was verified that, for children aged between 4 and 5 years, plaque removal from lingual surfaces could be improved with the utilization of an electric toothbrush. This result suggests that the electric toothbrush could improve plaque removal in areas of difficult access, for children with primary dentition. These findings are in agreement with the results reported by KHAMBAY; WALMSLEY ${ }^{7}$ (1995), GALGUT ${ }^{4}$ (1996) and AINAMO et al. ${ }^{1}$ (1997). Conversely, TRITTEN; ARMITAGE ${ }^{10}$ (1996) found out that plaque removal by means of manual and electric toothbrushes was equivalent for facial and lingual surfaces of anterior teeth. 
COSTA, C. C. da; COSTA FILHO, L. C. da; SÓRIA, M. L.; MAINARDI, A. P. R. Plaque removal by manual and electric toothbrushing among children. Pesqui Odontol Bras, v. 15, n. 4, p. 296-301, out./dez. 2001.

In this study, there were no statistical differences between the electric and manual toothbrushes regarding plaque removal for children aged from 10 to 12 years. Likewise, the study of MANTOKOUDIS et al. ${ }^{8}$ (2001) stated that, when manual and electric toothbrushes are compared in a group of people who were trained to use manual toothbrushes, both devices are equally effective in removing plaque from all considered surfaces.

A possible explanation for the best performance presented by children with primary dentition utilizing electric toothbrush is that, for small children (4 to 5 years old), both kinds of toothbrushes are novelties. Therefore, an extra benefit was provided when electric toothbrushes were utilized by subjects who did not have their manual dexterity totally developed. On the other hand, the results regarding children with mixed dentition could be partially explained by the fact that these children have been using manual toothbrushes for years, but have never used electric toothbrushes. For further research on the topic, longer training periods with the electric toothbrush may be necessary for children with mixed dentition, in order to obtain more accurate results.

\section{CONCLUSION}

The findings of the present study, which compared the electric toothbrush Braun Oral-B Ultra Plaque Remover with the manual toothbrush Squish Grip (Oral-B) in children with primary and mixed dentitions, demonstrated that the utilization of the electric toothbrush could improve supragingival plaque removal, especially in areas of difficult access, such as lingual surfaces, for children aged from 4 to 5 years. However, the same result was not observed in children with mixed dentition, for whom both toothbrushes were equivalent.

COSTA, C. C. da; COSTA FILHO, L. C. da; SÓRIA, M. L.; MAINARDI, A. P. R. Remoção de placa bacteriana pela escovação elétrica e manual em crianças. Pesqui Odontol Bras, v. 15, n. 4, p. 296-301, oct./dez. 2001.

A proposta deste estudo foi comparar a eficácia da remoção de placa bacteriana pelas escovações elétrica e manual. Quinze crianças portadoras de dentadura decídua e 14 crianças portadoras de dentadura mista foram divididas em dois grupos e, aleatoriamente, designadas a utilizar a escova manual ou a escova elétrica. Na primeira sessão, foi realizada completa remoção de placa bacteriana e após, as crianças permaneceram 24 horas sem escovar os dentes. Na segunda sessão, foi feita revelação de placa bacteriana e computação de seu índice para todas as faces vestibulares e linguais dos dentes. Depois, todos os participantes escovaram os dentes com a escova predeterminada. A próxima etapa foi a revelação e medição da placa residual. Decorridos 7 dias, as crianças trocaram para a outra escova dental e os mesmos procedimentos foram realizados. De acordo com os resultados, não houve diferença estatisticamente significante na remoção de placa bacteriana quando as escovas foram usadas por crianças em fase de dentição mista. No entanto, a escova elétrica removeu significativamente mais placa bacteriana nas faces linguais das crianças com dentição decídua.

UNITERMOS: Higiene oral; Escovação dentária; Dispositivos para o cuidado bucal domiciliar.

\section{BIBLIOGRAPHIC REFERENCES}

1. AINAMO, J.; XIE, Q.; AINAMO, A.; KALLIO, P. Assessment of the effect of an oscillating/rotating electric toothbrush on oral health. A 12-month longitudinal study. $\mathbf{J}$ Clin Periodontol, v. 24, n. 1, p. 28-33, Jan. 1997.

2. AASS, A. M.; GJERMO, P. Comparison of oral hygiene efficacy of one manual and two electric toothbrushes. Acta Odontol Scand, v. 58, n. 4, p. 166-170, Aug. 2000.

3. ENGEL, D.; NESSLY, M.; MORTON, T. et al. Safety testing of a new electronic toothbrush. J Periodontol, v. 64, n. 10, p. 941-946, 1993.

4. GALGUT, P. Efficacy of a new electronic toothbrush in removing bacterial dental plaque in young adults. Gen Dent, v. 44, n. 5, p. 441-445, Sept./Oct. 1996.

5. GROSSMAN, E.; PROSKIN, H. A comparison of the efficacy and safety of an electric and a manual children's tooth- brush. J Am Dent Assoc, v. 128, n. 4, p. 469-474, Apr. 1997.

6. HEINTZE, S.; JOST-BRINKMANN, P.; LOUNDOS, J. Effectiveness of three different types of electric toothbrushes compared with a manual technique in orthodontic patients. Am J Orthod Dentofacial Orthop, v. 110, n. 6, p. 630-638, Dec. 1996.

7. KHAMBAY, B.; WALMSLEY, A. An in vitro evaluation of electric toothbrushes. Quintessence Int, v. 25, n. 12, p. 841-848, Dec. 1995.

8. MANTOKOUDIS, D.; JOSS, A.; CHRISTENSEN, M. M. et al. Comparison of the clinical effects and gingival abrasion aspects of manual and electric toothbrushes. J Clin Periodontol, v. 28, n. 1, p. 65-72, 2001.

9. TRITTEN, C.; ARMITAGE, G. Comparison of a sonic and a manual toothbrush for efficacy in supragingival plaque removal and reduction of gingivitis. J Clin Periodontol, v. 23, n. 7, p. 641-648, July 1996. 
COSTA, C. C. da; COSTA FILHO, L. C. da; SÓRIA, M. L.; MAINARDI, A. P. R. Plaque removal by manual and electric toothbrushing among children. Pesqui Odontol Bras, v. 15, n. 4, p. 296-301, out./dez. 2001.

10. VAN DER WEIJDEN, F.; TIMMERMAN, M. F.; SNOEK, I. M. et al. Toothbrushing duration and plaque removing efficacy of electric toothbrushes. Am J Dent, v. 9, p. 31-36, 1996. Special issue.

11. VAN DER WEIJDEN, F. A.; TIMMERMAN, M. F.; PISKER, M. et al. A comparison of the efficacy of a novel electric toothbrush and a manual toothbrush in the treatment of gingivitis. Am J Dent, v. 11, p. 23-28, 1998. Special issue.
12. WALMSLEY, A. The electric toothbrush: a review. Br Dent J, v. 182, n. 6, p. 209-218, 1997.

13. WARREN, P. R.; CHATER, B. The role of electric toothbrush in the control of plaque and gingivitis: a review of 5 years of clinical experience with the Braun Oral-B Plaque Remover. Am J Dent, v. 9, p. 5-11, 1996. Special issue.

14. WHITE, L. Efficacy of a sonic toothbrush in reducing plaque and gingivitis in adolescent patients. J Clin Orthod, v. 30, n. 2, p. 85-90, 1996.

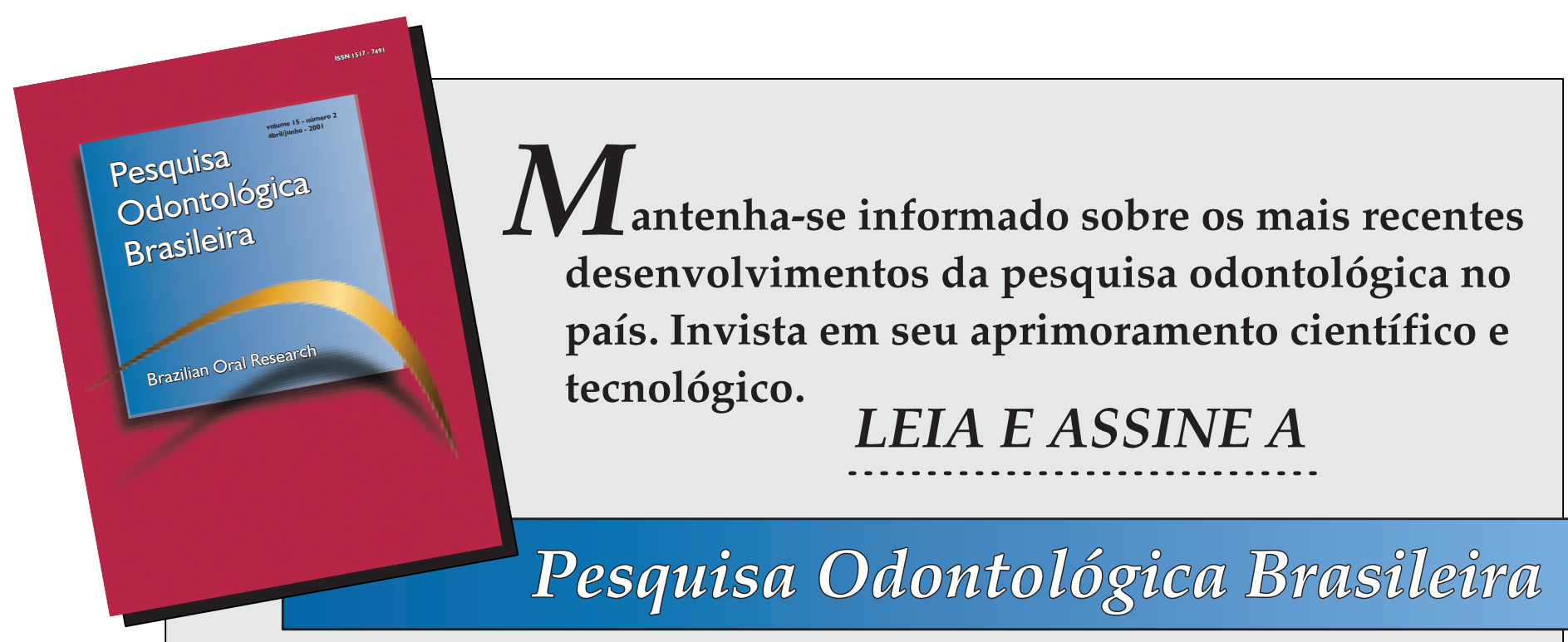

Valor da assinatura:

Publicação oficial da Sociedade

sócio da SBPqO: R\$ 50,00

Brasileira de Pesquisa Odontológica

não sócio da SBPqO: $R$ \$ 150,00

institucional: $\mathbf{R} \$ \mathbf{2 0 0 , 0 0}$

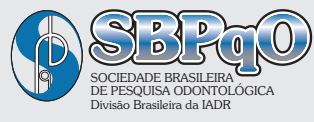

Envie carta contendo dados pessoais, endereço completo e

cheque nominal à "SBPqO / $\mathrm{POB}^{\prime}$, solicitando sua assinatura.

Endereço: SBPqO - Sociedade Brasileira de Pesquisa Odontológica

Av. Professor Lineu Prestes, 2227 - CEP 05508-900 - Cidade Universitária São Paulo - SP - Tel./fax: (0xx11) 3818-7855 - e-mail: sbpqo@sbpqo.org.br 